\title{
Expressão dos genes nodC, nodW e nopP em Bradyrhizobium japonicum estirpe CPAC 15 avaliada por RT-qPCR
}

\author{
Simone Bortolan ${ }^{(1)}$, Fernando Gomes Barcellos ${ }^{(2)}$, Francismar Corrêa Marcelino ${ }^{(3)}$ e Mariangela Hungria(3)
}

\begin{abstract}
(1)Universidade Estadual de Londrina, Departamento de Microbiologia, Caixa Postal 6001, Rodovia Celso Garcia Cid, PR 445, Km 380, Campus Universitário, CEP 86055-990 Londrina, PR. E-mail: sibortolan@yahoo.com.br (2)Universidade Paranaense, Caixa Postal 224, CEP 87502-210 Umuarama, PR. E-mail: fgbarcel@yahoo.com.br ${ }^{(3)}$ Embrapa Soja, Caixa Postal 231, CEP 86001-970 Londrina, PR. E-mail: francm@cnpso.embrapa.br, hungria@cnpso.embrapa.br
\end{abstract}

Resumo - O objetivo deste trabalho foi avaliar a expressão, por RT-qPCR, dos genes de nodulação nodC e nodW e do gene nopP da estirpe CPAC 15, que provavelmente atuam na infecção das raízes da soja. Foram realizados dois experimentos. No primeiro, a expressão dos genes foi avaliada nas células após a incubação com genisteína por $15 \mathrm{~min}, 1,4$ e 8 horas. Os resultados revelaram que os três genes apresentaram maior expressão imediatamente após o contato com o indutor $(15 \mathrm{~min})$. No segundo experimento, a bactéria foi cultivada na presença de indutores (genisteína ou exsudatos de sementes de soja) por 48 horas. A expressão dos três genes foi maior na presença de genisteína, com valores de expressão para nodC, nodW e nopP superiores ao controle. Os resultados obtidos confirmam a funcionalidade dos três genes na estirpe CPAC 15, com ênfase para o порP, cuja funcionalidade em Bradyrhizobium japonicum foi descrita pela primeira vez.

Termos para indexação: Glycine max, flavonoides, genes de nodulação, sistema de secreção tipo III.

\section{Expression of nodC, nodW and nopP genes in Bradyrhizobium japonicum CPAC 15 strain evaluated by RT-qPCR}

\begin{abstract}
The objective of this work was to evaluate, by RT-qPCR, the expression of the $\operatorname{nod} C$ and nod $W$ nodulation genes and of the nopP gene of the CPAC 15 strain, which probably play a role in the infection of soybean roots. Two experiments were done. In the first, the gene expression was evaluated in cells after incubation with genistein for $15 \mathrm{~min}, 1,4$ and 8 hours. Results showed that the three genes showed higher expression immediately after contact with the inducer $(15 \mathrm{~min})$. In the second experiment, the bacterium was grown in the presence of inducers (genistein or soybean seed exudates) for 48 hours. The expression of the three genes was greater when induced by genistein, and the expression of $\operatorname{nod} C, \operatorname{nod} W$ and $n o p P$ had higher values than the control. The results confirm the functionality of the three genes in the CPAC 15 strain, with an emphasis on the nopP, whose functionality in Bradyrhizobium japonicum was described for the first time.
\end{abstract}

Index terms: Glycine max, flavonoids, nodulation genes, type III secretion system.

\section{Introdução}

Uma característica relevante da cultura da soja (Glycine $\max$ (L.) Merr.) é sua capacidade de se associar simbioticamente com algumas espécies de bactérias e estabelecer o processo de fixação biológica do nitrogênio, que pode suprir totalmente as necessidades da planta. As principais bactérias capazes de atuar simbioticamente com a soja pertencem às espécies Bradyrhizobium japonicum e B. elkanii, e o processo de fixação biológica envolve a transcrição de diversos genes relacionados à nodulação e ao processo de fixação do nitrogênio (Lang et al., 2008; Wei et al., 2008). B. japonicum tem sido a espécie utilizada como modelo nos estudos da simbiose com soja e, na etapa inicial de transcrição dos genes de nodulação, sinais moleculares, especialmente os flavonoides genisteína e daidzeína, são exsudados pela soja e controlam a ativação da proteína regulatória NodD1. Essa proteína, por sua vez, dá início à transcrição dos genes $\operatorname{nod} A B C$, e resulta na síntese, pelas bactérias, de compostos lipo-quito-oligossacarídeos (LCOs), ou fatores Nod, essenciais para as etapas iniciais de infecção e nodulação da planta hospedeira (Kosslak et al., 1987; Hungria \& Stacey, 1997; Debellé et al., 2001; Brencic \& Winans, 2005).

Outro mecanismo envolvido na simbiose com a soja atua na transcrição dos genes nod $A B C$ e é conhecido como sistema de dois componentes, sendo representado pelas proteínas reguladoras NodV (sensora) e NodW

Pesq. agropec. bras., Brasília, v.44, n.11, p.1491-1498, nov. 2009 
(reguladora). Na presença de flavonoides indutores exsudados pela planta hospedeira, a proteína NodV da bactéria é fosforilada, e o fosfato resultante é transferido para a proteína NodW, que passa a se ligar à sequência de DNA da região dos genes $\operatorname{nod} A B C$, ativando a sua transcrição (Bijlsma \& Groisman, 2003).

Para que a infecção das raízes de soja seja efetiva, microssimbiontes como B. japonicum também utilizam o sistema de secreção do tipo III (SSTT). Esse sistema tem por finalidade formar um aparato semelhante a uma agulha, que atravessa a membrana da célula hospedeira e injeta proteínas efetoras, as "nodulation outer proteins" (Nops), que atuarão no citoplasma da célula, alterando o seu metabolismo e causando supressão das defesas basais contra o microrganismo, o que possibilita a infecção das raízes pelo rizóbio (Büttner \& Bonas, 2006). Desse modo, quando a região reguladora "box" do operon nodABC é ativada pelas proteínas NodD1 e $N o d W$, além da transcrição dos genes de nodulação, ocorre também a transcrição do gene ttsI, relacionado ao SSTT. A proteína codificada por esse gene, a TtsI, ativa a transcrição de genes como o nopP, culminando na secreção da proteína efetora NopP, que impedirá a resposta de defesa do hospedeiro (Lang et al., 2008). Supõe-se que NopP atue suprimindo as defesas do hospedeiro, inibindo a reposta de hipersensibilidade e, assim auxiliando no desenvolvimento da infecção (Saad et al., 2005). As indicações são de que a ativação do gene nopP acontece por meio de uma cascata, começando com o acionamento da proteína NodD1 pelo flavonoide, que se liga ao nod "box" e ativa os genes nod $A B C$ e o "box" ttsI, que codifica para a proteína TtsI, cuja função é ativar a expressão do gene nopP (Krause et al., 2002). Além da expressão do nopP "via NodD1", esse gene pode ser acionado pelo sistema de dois componentes quando a proteína reguladora NodW se liga ao nod "box", desencadeando a mesma cascata até a ativação do gene nopP (Loh et al., 2002). A estirpe CPAC 15 (= SEMIA 5079) de B. japonicum é uma das quatro estirpes recomendadas para a produção de inoculantes comerciais para soja no Brasil, e vem sendo utilizada intensivamente em inoculantes comerciais desde 1992. Estima-se que esteja presente em mais de 20 milhões de hectares cultivados com essa leguminosa (Hungria et al., 2006, 2007). Estudos de ecologia da CPAC 15 realçam a grande capacidade competitiva e de adaptação dessa estirpe aos solos brasileiros, que em geral é dominante no solo após alguns anos de cultivo da soja (Mendes et al., 2004; Hungria et al., 2006; Batista et al., 2007).

Apesar da grande importância econômica e ambiental das estirpes utilizadas em inoculantes comerciais para a cultura da soja no Brasil, os estudos sobre genômica estrutural e funcional envolvendo esses rizóbios são muito escassos. Informações foram obtidas recentemente pelo sequenciamento parcial do genoma da estirpe CPAC 15 de B. japonicum (Godoy et al., 2008), onde foram identificados os genes objeto deste estudo.

O objetivo deste trabalho foi avaliar a expressão, pela técnica de RT-qPCR (reverse transcription quantitative PCR), dos genes nod $C$, nod $W$ e nopP da estirpe CPAC 15 de $B$. japonicum, envolvidos nas etapas de infecção e nodulação da soja.

\section{Material e Métodos}

A expressão dos genes $\operatorname{nod} C, \operatorname{nod} W$ e $\operatorname{nod} P$ foi averiguada na presença de dois indutores: i, a genisteína, inicialmente identificada em extratos de raízes de soja (Kosslak et al., 1987) e, desde então, utilizada na maioria dos estudos de indução gênica com os rizóbios microssimbiontes dessa leguminosa; e ii, exsudatos de sementes da cultivar de soja Conquista, com excelente capacidade de nodulação. A genisteína foi utilizada na concentração de $1 \mu \mathrm{mol} \mathrm{L}{ }^{-1}$. Os exsudatos de sementes de soja foram preparados como descrito por Hungria et al. (1991a, 1996) e, que em um estudo prévio com a CPAC 15, resultaram em abundante produção de fatores Nod (Hungria et al., 1996).

Foram feitos dois experimentos: um para verificar a expressão gênica pela indução com o flavonoide genisteína em diferentes tempos de incubação e o outro para avaliar a indução dos genes em bactérias cultivadas na presença de genisteína e exsudatos de sementes de soja.

O experimento para avaliar a expressão de genes envolvidos na nodulação pela ação da genisteína, nos tempos iniciais de nodulação, seguiu um delineamento em blocos ao acaso, com três repetições, cada uma com três replicatas e dois fatores: tempo (15 min, 1, 4 e 8 horas) e indutor genisteína - preparada utilizando o metanol como solvente, na concentração final de $1 \mu \mathrm{mol}$ $\mathrm{L}^{-1}$ em $200 \mu \mathrm{L}$ de metanol -, e o controle-somente com o uso do solvente, $200 \mu \mathrm{L}$ de metanol. 
A partir de um estoque inicial, a estirpe CPAC 15 de B. japonicum foi transferida para $10 \mathrm{~mL}$ de meio $\mathrm{TY}$ (triptone-yeast) líquido (Beringer, 1974) (pré-inóculo) e mantida sob agitação a $28^{\circ} \mathrm{C}$ por aproximadamente 72 horas até densidade ótica (D.O.) aproximada de 0,9 em $600 \mathrm{~nm}$. Então, $2 \mathrm{~mm}$ do pré-inóculo foram inoculados em $200 \mathrm{~mL}$ de meio TY líquido, e a cultura foi mantida sob agitação a $28^{\circ} \mathrm{C}$ por aproximadamente 48 horas (D.O. de 0,4 a 0,8 em $600 \mathrm{~nm}$ ). Em seguida, foi adicionada genisteína (Sigma, Missouri, EUA) na concentração final de $1 \mu \mathrm{mol} \mathrm{L} \mathrm{L}^{-1}$, dissolvida em $200 \mu \mathrm{L}$ de metanol. A concentração de genisteína foi estimada pelo seu coeficiente de extinção (loge = 4,50 em D.O. de $263 \mathrm{~nm}$, de genisteína dissolvida em metanol), conforme descrito por Hungria et al. (1991b). Após a adição da genisteína, foram realizadas as extrações de RNA para cada tempo de incubação, e os níveis de expressão dos genes nodC, nodW e nopP foram avaliados pela técnica de RT-qPCR (Livak \& Schmittgen, 2001).

Para o segundo experimento, para avaliar a expressão dos genes após a indução pela genisteína e por exsudatos de semente de soja, o delineamento experimental foi o de blocos ao acaso, com três repetições e quatro tratamentos. Inicialmente, a estirpe CPAC 15 foi transferida para $10 \mathrm{~mL}$ de meio TY líquido (pré-inóculo) e mantida sob agitação a $28^{\circ} \mathrm{C}$ por aproximadamente 72 horas. Dois mililitros do pré-inóculo foram adicionados em $200 \mathrm{~mL}$ de meio TY líquido e, para a indução da expressão dos genes, foram adicionados, separadamente, genisteína ou exsudatos de sementes de soja. Os exsudatos de soja foram preparados segundo Hungria et al. (1991a), e a concentração adicionada para incubação foi estimada considerando-se o coeficiente de extinção da genisteína. Foram utilizados quatro tratamentos: 1, $200 \mathrm{~mL}$ de cultura com genisteína $\left(1 \mu \mathrm{mol} \mathrm{L} \mathrm{L}^{-1}\right.$ em $200 \mu \mathrm{L}$ de metanol); 2, cultura com $200 \mu \mathrm{L}$ de metanol (sem adição de genisteína, como controle); 3, $200 \mathrm{~mL}$ de cultura com $890 \mu \mathrm{L}$ de exsudato de semente (concentração estimada em aproximadamente $1 \mu \mathrm{mol} \mathrm{L}{ }^{-1}$ de genisteína, considerado $\log \varepsilon=4,50 \mathrm{em}$ D.O. de $263 \mathrm{~nm}) ; 4,200 \mathrm{~mL}$ de cultura com adição de $890 \mu \mathrm{L}$ de água destilada, sem adição do exsudato. As culturas foram mantidas sob agitação a $28^{\circ} \mathrm{C}$ por aproximadamente 48 horas e, em seguida, procedeu-se à extração do RNA.

A extração do RNA foi realizada de acordo com a metodologia descrita por Farrell (1998).
Após a extração, procedeu-se à quantificação no espectrofotômetro NanoDrop ND - 1000 (Thermo Fischer Scientific, Massachusetts, EUA). Em seguida, foi realizado o tratamento do RNA com a enzima RNase-free DNase (Qiagen, Maryland, EUA), na concentração de 2 U para cada 1.000 ng de RNA, para eliminar qualquer contaminação por DNA. A reação foi incubada por 8 min a $37^{\circ} \mathrm{C}$ e interrompida com choque térmico a $60^{\circ} \mathrm{C}$ por $5 \mathrm{~min}$. Nas reações de transcrição reversa (síntese da primeira fita de cDNA), foi utilizado o kit TaqMan Reverse Transcription Reagents (Applied Biosystems, Foster, CA, EUA), conforme as instruções do fabricante.

Os primers utilizados foram desenhados com base nas sequências dos genes provenientes das estirpes CPAC 15 (Godoy et al., 2008) e USDA 110 de B. japonicum (depositadas no GenBank National Center for Biotechnology Information (2009)) com uso do software Primer Express v.3.0 (Applied Biosystems, Foster, CA, USA), e foram obtidos fragmentos de tamanho entre 50 e 150 pares de bases.

As sequências de primers para cada gene são para os genes: nodC, F (forward) -5'CACCAGGGTATAGAGCCATCGA3' e R (reverse)-5' ATTGCTCCTCGCCATTTCAT3'; nodW, F-5'CGAGATCACCGTCAAAATTCAC3' e R-5'GAACGAGGTCGGCCAGAGA3'; nopP, F-5'TGGAGATATAGGGATGGTGAATGG3' e R-5'ATCGCTCGACGCTTTGGA3'.

O gene utilizado como normalizador (controle endógeno) foi o $16 \mathrm{~S}$ rRNA, com a sequência de primers F-5'CAAGCGGTGGAGCATGTG3' e R-5'GGACATGTCAAGGGCTGGTAA3'.

As reações de RT-qPCR (reverse transcription quantitative PCR) foram realizadas no termociclador ABI Prism 7500 Sequence Detection System (Applied Biosystems, Foster, CA, EUA). Para as reações de RT-qPCR, foi usado o kit SYBR Green PCR Master Mix (Applied Biosystems, Foster, CA, EUA), conforme as instruções do fabricante.

A eficiência da reação de amplificação para cada par de primers dos genes estudados e do normalizador foi estimada por meio de uma série de diluições do cDNA(100 a 10-10), onde foram testadas diferentes concentrações dos primers $\left(0,1 ; 0,2 ; 0,3\right.$ e $\left.0,4 \mu \mathrm{mol} \mathrm{L}^{-1}\right)$. Os valores de $\mathrm{CT}$ (cycle threshold) obtidos foram traçados em função do logaritmo das diluições, e o coeficiente de inclinação da reta foi utilizado para calcular a eficiência de cada 
sistema, de acordo com a fórmula $E=\left[10^{-1 / \text { slope }}\right]-1$. Os parâmetros de ciclagemutilizados para as reações foram: ativação da enzima a $95^{\circ} \mathrm{C}$ por $10 \mathrm{~min}$, seguida de 40 ciclos de $95^{\circ} \mathrm{C}$ por $15 \mathrm{~s}$ para o anelamento, e extensão a $60^{\circ} \mathrm{C}$ por $1 \mathrm{~min}$. Os dados foram coletados nesta última etapa. Adicionalmente, foi conduzida uma etapa de desnaturação lenta, com elevação da temperatura de $1{ }^{\circ} \mathrm{C}$ por min para a construção da curva de dissociação. Considerando que os fragmentos gerados apresentam temperatura de desnaturação específica, é possível detectar a presença de amplificação inespecífica em uma mesma reação.

A reação de quantificação relativa foi realizada utilizando-se as seguintes quantidades: reação i, gene normalizador $-12,5 \mu \mathrm{L}$ de SYBR Green PCR Master Mix 2X (composto pelas enzimas uracil $\mathrm{N}$-glicosilase e AmpliTaq Gold, MgCl2, dNTPs, $\mathrm{KCl}$ e o fluoróforo SYBR green); $1 \mu \mathrm{L}(0,4 \mu \mathrm{mol}$ $\mathrm{L}^{-1}$ ) de cada primer R e F; $2,5 \mu \mathrm{L}$ de cDNA e $8 \mu \mathrm{L}$ de água milliQ (Millipore Corporation, Billerica, MA, EUA); reação ii, genes alvo - 12,5 $\mu \mathrm{L}$ de SYBR Green PCR Master Mix 2X; 0,8 $\mu \mathrm{L}\left(0,32 \mu \mathrm{mol} \mathrm{L}^{-1}\right)$ de cada primer R e F; $2,5 \mu \mathrm{L}$ de cDNA e $8,4 \mu \mathrm{L}$ de água milliQ. Os parâmetros de ciclagem foram os mesmos descritos para os cálculos de eficiência da reação de amplificação.

A determinação dos níveis de expressão dos genes alvo foi realizada pela quantificação relativa (RQ), utilizando-se a equação $R Q=2^{-\Delta \Delta C}{ }_{T}$ (Livak \& Schmittgen, 2001). Para cada tratamento, foi detectado o valor de $\mathrm{C}_{\mathrm{T}}$ tanto para o gene alvo quanto para o normalizador. Esse valor representa o ponto em que o sinal de amplificação é detectado. $\mathrm{O}$ valor do $\mathrm{C}_{\mathrm{T}}$ do gene alvo é subtraído do valor do $\mathrm{C}_{\mathrm{T}}$ do normalizador e resulta no valor de $\Delta \mathrm{C}_{\mathrm{T}}$; o valor de $\Delta \mathrm{C}_{\mathrm{T}}$ do gene alvo é, então, subtraído do valor do $\Delta \mathrm{C}_{\mathrm{T}}$ do calibrador (controle não tratado), e é encontrado o valor de $\Delta \Delta \mathrm{C}_{\mathrm{T}}$. Este valor foi utilizado na fórmula do nível de expressão, onde o número 2 representa a somatória da eficiência do gene alvo e do normalizador, considerando que ambos os genes possuem $100 \%$ de eficiência (Livak \& Schmittgen, 2001).

A análise dos dados foi feita por estatística descritiva com o software Prism versão 3.0 (GraphPad Software Inc., San Diego, CA, EUA). A reprodutibilidade e precisão dos valores de RQ obtidos foram estimadas pelos desvios-padrão (SD) em cada corrida e entre as corridas.

\section{Resultados e Discussão}

No primeiro experimento conduzido, a expressão dos genes nodC, nodW e nopP foi investigada utilizando o flavonoide genisteína como indutor. Aos 15 min de indução, houve um incremento, estimado em 1,5 vezes, na expressão do gene nodC em comparação ao controle contendo metanol no mesmo tempo seguido por uma queda na expressão gênica nos demais tempos de incubação (Figura 1). Resultados semelhantes foram obtidos com os genes nodW e nopP, nos quais foram observados incrementos de 1,67 e 1,42 vezes, respectivamente, na expressão gênica aos 15 min, seguidos por decréscimos nos demais tempos (Figura 1).

No segundo experimento, a expressão dos genes foi investigada em células incubadas por 48 horas com genisteína $\left(1 \mu \mathrm{mol} \mathrm{L}^{-1}\right)$ ou com exsudatos de sementes de soja. Os níveis de expressão gênica constatados foram muito superiores àqueles do ensaio anterior. No caso do nodC, houve um acréscimo de 7,30 vezes na expressão gênica na presença de genisteína em comparação com o controle (Figura 2). De modo semelhante, a indução dos genes nodW e nopP pela genisteína foi 6,54 e 7,85 vezes superior à do controle (Figura 2), respectivamente. Houve também um

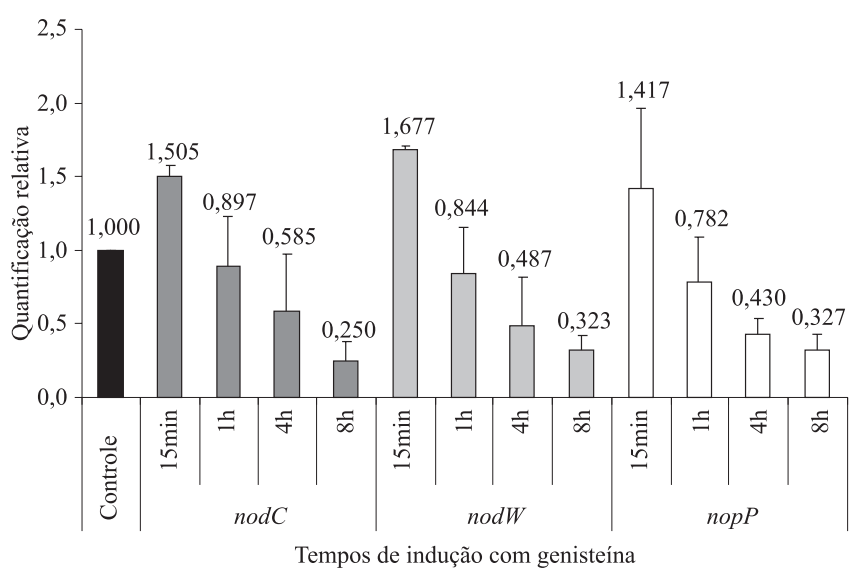

Figura 1. Expressão dos genes nopP, nodW e $\operatorname{nod} C$ de Bradyrhizobium japonicum estirpe CPAC 15 incubada por diferentes tempos em meio de cultura com genisteína $\left(1 \mu \mathrm{mol} \mathrm{L}{ }^{-1}\right)$. Os valores representam as médias \pm desviopadrão da média de três repetições, cada uma com três replicatas. A quantificação relativa foi estimada pela equação RQ $=2^{-\Delta \Delta \mathrm{C}_{\mathrm{T}}}$ (Livak \& Schmittgen, 2001). Controle (tempos de 15 min, 1, 4 e 8 horas), CPAC 15 cultivada em meio com $200 \mu \mathrm{L}$ de metanol. 
incremento na expressão dos genes nodC, nod $W$ e nopP quando a bactéria cresceu na presença de exsudatos de sementes de soja. Contudo, os incrementos foram de menor magnitude em comparação com a incubação com $1 \mu \mathrm{mol} \mathrm{L}{ }^{-1}$ de genisteína. Assim, o nível de expressão dos genes nodC, nodW e nopP na presença de exudatos de sementes de soja foi 2,32, 2,94 e 2,00 vezes superior ao do controle com água (Figura 2), respectivamente.

Trabalhando com expressão gênica em $B$. japonicum USDA 110 sob indução com exsudatos de sementes de soja e genisteína, Wei et al. (2008) demonstraram que ambos incrementaram de modo semelhante à expressão dos genes nodC e nodW. Contudo, neste trabalho, a maior expressão pela genisteína (Figura 2) pode resultar da constatação de que os exsudatos de sementes compreendem vários compostos (incluindo uma complexidade de flavonoides), os quais podem interagir, sendo relatada, em alguns casos, a ocorrência da inibição da expressão dos genes de nodulação (Hungria \& Stacey, 1997). O fato de neste trabalho ter sido identificada maior expressão induzida pela genisteína, com relação ao exsudato, em comparação aos resultados obtidos por Wei et al. (2008), também pode estar relacionado ao tempo de indução analisado. Neste trabalho, a expressão dos genes $\operatorname{nod} C$ e $\operatorname{nod} W$

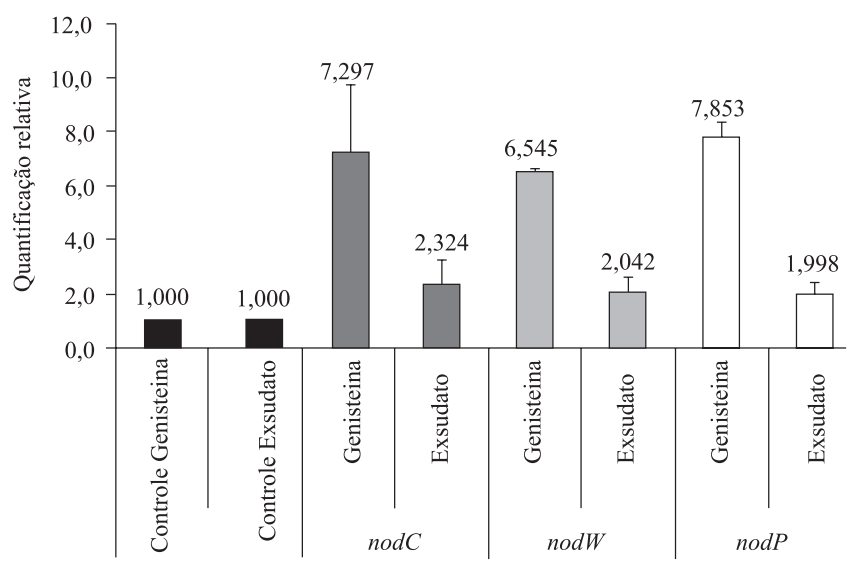

Figura 2. Expressão dos genes nopP, nodW e nodC de Bradyrhizobium japonicum estirpe CPAC 15 cultivada em meio contendo os indutores genisteína $\left(1 \mu \mathrm{mol} \mathrm{L} \mathrm{L}^{-1}\right)$ ou exsudatos de sementes de soja. Os valores representam as médias \pm desvio-padrão da média de três repetições, cada uma com três replicatas. A quantificação relativa foi estimada pela equação $R Q=2^{-\Delta \Delta \mathrm{C}_{\mathrm{T}}}$ (Livak \& Schmittgen, 2001). Controle genisteína, meio de cultivo com adição de $200 \mu \mathrm{L}$ de metanol; Controle exsudato, meio de cultivo com adição de $890 \mu \mathrm{L}$ de água destilada.
(Figura 2) foi avaliada após 48 horas de indução, enquanto nos resultados apresentados por Wei et al. (2008), a expressão desses genes foi avaliada após os períodos de $50 \mathrm{~min}, 6$ e 12 horas.

Os resultados obtidos nos dois experimentos conduzidos neste estudo indicam que, após apenas 15 min de indução por genisteína, ocorreu um incremento na expressão dos genes $\operatorname{nod} C$, nodW e nop $P$, mas que foi seguido por um decréscimo na expressão gênica (Figura 1). Esse decréscimo poderia ser explicado pela constatação de que, em procariotos, os mRNAs são transcritos e traduzidos em um mesmo compartimento celular. Ambos processos são extremamente relacionados e, inclusive, ocorrem praticamente de modo simultâneo. Além disso, os mRNAs são instáveis em procariotos, com meia-vida de apenas alguns minutos (em média, apenas $2 \mathrm{~min}$ ), e a degradação do mRNA ocorre assim que a tradução termina (Condon, 2007). Consequentemente, após a expressão dos genes, a degradação dos mRNAs poderia explicar os decréscimos observados neste estudo. Valores mais elevados de expressão gênica, porém, foram obtidos quando as células foram cultivadas na presença de indutores, em especial de genisteína (Figura 2), e não existem, na literatura, dados comparativos sobre a indução de genes de rizóbios em diferentes estádios do crescimento das bactérias.

A proteína NodC atua na biossíntese da estrutura básica dos fatores Nod (Spaink et al., 1994), mais especificamente como um determinante importante do tamanho da cadeia do fator Nod (Kamst et al., 1997). Ausmees et al. (2004), em estudo com Rhizobium sp. NGR234, relataram que os genes nod $A B C$ são transcritos em poucos minutos após a indução por flavonoides, por participarem da fase inicial do processo de nodulação. De modo semelhante, Viprey et al. (1998), também com Rhizobium sp. NGR 234 descreveram que genes do operon nodABC possuem maior expressão no período anterior a uma hora de indução pelo flavonoide. De fato, neste trabalho com a CPAC 15 foi evidenciado que o incremento na expressão do gene nodC pode ocorrer rapidamente após o contato com o indutor (15 min), embora níveis mais elevados de expressão gênica tenham sido observados quando a estirpe foi cultivada na presença de indutores por 48 horas, desde a fase inicial de crescimento. Contudo, o efeito dos indutores pode ser diferente para outras classes de genes. Como exemplo, a expressão de genes relacionados ao SSTT 
(sistema de transcrição do tipo III) de B. japonicum estirpe USDA 110 foi maior na presença de genisteína nas primeiras seis horas de incubação, enquanto que, para o tempo de 12 horas, a maior expressão ocorreu com exsudatos de soja (Wei et al., 2008).

No sistema de dois componentes composto pelas proteínas NodV (proteína sensora) e NodW (proteína reguladora), NodV, na presença do indutor (genisteína), se autofosforila e transfere o grupo fosfato à proteína NodW, alterando sua capacidade de se ligar à região reguladora dos genes nod e ativando a expressão dos genes nod $A B C$ (Loh et al., 1997, 2002; Bijlsma \& Groisman, 2003). Em um estudo com a estirpe USDA 110 de B. japonicum, Wei et al. (2008) constataram que os genes nodW e $n o d V$ e o operon $\operatorname{nod} A B C$ são ativados na presença de genisteína no estágio inicial do processo de nodulação. Além disso, ainda no estudo de Wei et al. (2008), o nível de expressão do $\operatorname{nod} W$, quando induzido tanto pela genisteína quanto por exsudatos de sementes de soja, foi incrementado $30 \mathrm{~min}$ após a indução, porém, o maior nível de expressão foi detectado após 6 horas. Assim como foi observado no presente trabalho (Figura 1), o aumento na expressão dos genes nodW de B. japonicum estirpe USDA 110 por genisteína aos 15 min foi seguido por uma redução na expressão (Wei et al., 2008). Esse decréscimo pode estar relacionado, como foi comentado para o nodC, à degradação rápida dos mRNAs, bem como ao fato de o gene nodW atuar no início da cascata de ativação dos genes relacionados ao processo de nodulação, codificando para uma proteína reguladora dos genes nodABC. Desse modo, a redução na expressão do gene pode estar relacionada à proteína ter sido codificada em níveis suficientes para o processo. Os resultados deste estudo confirmam relatos anteriores de expressão do gene nodW de B. japonicum por flavonoides ou exsudatos de soja (Lang et al., 2008; Wei et al., 2008), sendo um gene crítico para a nodulação da planta hospedeira.

Segundo Süss et al. (2006), em rizóbios, a secreção de proteínas pelo SSTT necessita de indução por flavonoides. Além disso, nesse estudo, os autores identificaram proteínas extracelulares induzidas por genisteína em B. japonicum por meio de análise por 2D-PAGE e espectrofotometria de massa, na qual foi encontrada uma proteína similar à NopP de
Rhizobium NGR234; contudo, o primeiro relato do gene nopP em $B$. japonicum ocorreu com a estirpe CPAC 15 (Godoy et al., 2008). Ausmees et al. (2004), em um trabalho sobre a caracterização da proteína NopP em Rhizobium sp. NGR234, confirmaram, por meio da análise de mutantes por SDS-PAGE, que a secreção da NopP é dependente da presença de flavonoides e do SSTT, e que a transcrição dos genes relacionados com o SSTT ocorre várias horas após a indução com o flavonoide. Viprey et al. (1998) também mostraram, com indução gênica em Rhizobium sp. NGR234 por daidzeína, que a expressão dos genes do SSTT é tardia quando comparada à expressão dos genes de nodulação. No estudo com a estirpe NGR234, após uma hora de indução, os genes do SSTT foram pouco expressos, ao contrário dos genes nod envolvidos na síntese e modificação dos fatores de nodulação; contudo, após 24 horas de indução, essa situação foi revertida, e os genes relacionados ao SSTT foram transcritos, enquanto outros genes de nodulação foram reprimidos (Viprey et al., 1998). De forma diferente da descrita acima, neste estudo, a máxima indução de nopP ocorreu após 15 min de incubação com genisteína, o que pode ser atribuído a diferenças intrínsecas à estirpe CPAC 15 ou ao fato de que períodos curtos de incubação não foram avaliados nos estudos anteriores. É importante enfatizar que, neste estudo, a funcionalidade do gene nopP foi confirmada pela primeira vez em $B$. japonicum, tendo sido verificada a expressão do gene quando induzido com genisteína ou com exsudatos de sementes de soja. Saad et al. (2005) relataram que a ausência das proteínas efetoras (Nops) altera drasticamente a capacidade de nodulação em Rhizobium sp NGR234. Ainda mais relevante é o fato de que, em um estudo comparativo por RDA (representational difference analysis) de mutantes naturais com diferentes capacidades de fixação do nitrogênio, o gene nopP estava entre as 24 sequências que foram encontradas exclusivamente na estirpe altamente eficaz no processo biológico (Barcellos et al., 2009). Desse modo, a confirmação de que nopP é funcional em $B$. japonicum reforça que estudos com esse gene podem ser de grande relevância, visando tanto compreender os mecanismos de competitividade e eficiência do processo de fixação do nitrogênio, como buscar estirpes promissoras para o uso em inoculantes comerciais. 


\section{Conclusões}

1. Os genes de nodulação nodC e $\operatorname{nod} W$ da estirpe CPAC 15 de Bradyrhizobium japonicum são funcionais e induzidos por genisteína e por exsudatos de sementes de soja.

2. Pela primeira vez foi descrita a funcionalidade do gene nopP em $B$. japonicum, que também é induzido por genisteína e por exsudatos de sementes de soja.

\section{Agradecimentos}

À Luciana R. Oliveira, pelo auxílio na condução dos experimentos, e à Elisete P. Rodrigues, pela discussão dos resultados; à Empresa Brasileira de Pesquisa Agropecuária, pela bolsa de pesquisa.

\section{Referências}

AUSMEES, N.; KOBAYASHI, H.; DEAKIN, W.J.; MARIE, C.; KRISHNAN, H.B.; BROUGHTON, W.J.; PERRET, X. Characterization of NopP, a type III secreted effector of Rhizobium sp. strain NGR234. Journal of Bacteriology, v.186, p.4774-4780, 2004.

BARCELLOS, F.G.; BATISTA, J.S. da S.; MENNA, P.; HUNGRIA, M. Genetic differences between Bradyrhizobium japonicum variant strains contrasting in N2-fixation efficiency revealed by representational difference analysis. Archives of Microbiology, v.191, p.113-122, 2009.

BATISTA, J.S. da S.; HUNGRIA, M.; BARCELLOS, F.G.; FERREIRA, M.C.; MENDES, I.C. Variability in Bradyrhizobium japonicum and B. elkanii seven years after introduction of both the exotic microsymbiont and the soybean host in a Cerrados soil. Microbial Ecology, v.53, p.270-284, 2007.

BERINGER, J.E. A factor transfer in Rhizobium leguminosarum. Journal of General Microbiology, v.84, p.188-198, 1974.

BIJLSMA, J.J.E.; GROISMAN, E.A. Making informed decisions: regulatory interactions between two-component systems. Trends in Microbiology, v.11, p.350-366, 2003.

BRENCIC, A.; WINANS, S.C. Detection of and response to signals involved in host-microbe interactions by plant-associated bacteria. Microbiology and Molecular Biology Reviews, v.69, p.155-194, 2005.

BÜTTNER, D.; BONAS, U. Who comes first? How plant pathogenic bacteria orchestrate type III secretion. Current Opinion in Microbiology, v.9, p.193-200, 2006.

CONDON, C. Maturation and degradation of RNA in bacteria. Current Opinion in Microbiology, v.10, p.271-278, 2007.

DEBELlÉ, F.; MOULIN, L.; MANGIN, B.; DÉNARIÉ, J.; BOIVIN, C. nod genes and Nod signals and the evolution of the rhizobium legume simbiosis. Acta Biochimica Polonica, v.48, p.359-365, 2001.
FARRELL, R.E. RNA methodologies: a laboratory guide for isolation and characterization. $2^{\text {nd }}$ ed. San Diego: Academic, 1998. $533 \mathrm{p}$.

GODOY, L.P.; VASCONCELOS, A.T.R.; CHUEIRE, L.M.O.; SOUZA, R.C.; NICOLÁS, M.F.; BARCELLOS, F.G.; HUNGRIA, M. Genomic panorama of Bradyrhizobium japonicum CPAC 15, a commercial inoculant strain largely established in Brazilian soils and belonging to the same serogroup as USDA 123. Soil Biology \& Biochemistry, v.40, p.2742-2753, 2008.

HUNGRIA, M.; CAMPO, R.J.; MENDES, I.C. A importância do processo de fixação biológica do nitrogênio para a cultura de soja: componente essencial para a competitividade do produto brasileiro. Londrina: Embrapa Soja, 2007. 80p. (Embrapa Soja. Documentos, 283).

HUNGRIA, M.; CAMPO, R.J.; MENDES, I.C.; GRAHAM, P.H. Contribution of biological nitrogen fixation to the $\mathrm{N}$ nutrition of grain crops in the tropics: the success of soybean (Glycine max L. Merr.) in South America. In: SINGH, R.P.; SHANKAR, N.; JAIWAL, P.K., (Ed.). Nitrogen nutrition in plant productivity. Houston: Studium, 2006. p.43-93.

HUNGRIA, M.; JOSEPH, C.M.; PHILLIPS, D.A. Anthocyanidins and flavonols, major nod gene inducers from seeds of a blackseeded common bean (Phaseolus vulgaris L.). Plant Physiology, v.97, p.751-758, 1991a.

HUNGRIA, M.; JOSEPH, C.M.; PHILLIPS, D.A. Rhizobium nod gene inducers exude d naturally from roots of common bean (Phaseolus vulgaris L.). Plant Physiology, v.97, p.759-764, 1991b.

HUNGRIA, M.; NISHI, C.Y.M.; COHN, J.; STACEY, G. Comparison between parental and variant soybean Bradyrhizobium strains with regard to the production of lipo-chitin nodulation signals, early stages of root infection, nodule occupancy, and N2 fixation rates. Plant and Soil, v.186, p.331-341, 1996.

HUNGRIA, M.; STACEY, G. Molecular signals exchanged between host plants and rhizobia: basic aspects and potential application in agriculture. Soil Biology \& Biochemistry, v.29, p.819-830, 1997.

KAMST, E.; PILLING, J.; RAAMSDONK, L.M.; LUGTENBERG, B.J.J.; SPAINK, H.P. Rhizobium nodulation protein NodC is an important determinant of chitin oligosaccharide chain length in Nod factor biosynthesis. Journal of Bacteriology, v.179, p.2103$2108,1997$.

KOSSLAK, R.M.; BOOKLAND, R.; BARKEY, J.; PAAREN, H.E.; APPELBAUM, E.R. Induction of Bradyrhizobium japonicum common nod genes by isoflavones isolated from Glycine max. Proceedings of the National Academy of Sciences of the United States of America, v.84, p.7428-7432, 1987.

KRAUSE, A.; DOERFEL, A.; GÖTTFERT, M. Mutational and transcriptional analysis of the type III secretion system of Bradyrhizobium japonicum. Molecular Plant-Microbe Interactions, v.15, p.1228-1235, 2002.

LANG, K.; LINDEMANN, A.; HAUSER, F.; GÖTTFERT, M. The genistein stimulon of Bradyrhizobium japonicum. Molecular Genetics and Genomics, v.279, p.203-211, 2008. 
LIVAK, K.J.; SCHMITTGEN, T.D. Analysis of relative gene expression data using real-time quantitative PCR and the 2(-Delta Delta C(T)) method. Methods, v.25, p.402-408, 2001.

LOH, J.; GARCIA, M.; STACEY, G. NodV and NodW, a second flavonoid recognition system regulating nod gene expression in Bradyrhizobium japonicum. Journal of Bacteriology, v.179, p.3013-3020, 1997.

LOH, J.; LOHAR, D.P.; ANDERSEN, B.; STACEY, G. A twocomponent regulator mediates population-density-dependent expression of the Bradyrhizobium japonicum nodulation genes. Journal of Bacteriology, v.184, p.1759-1766, 2002.

MENDES, I.C.; HUNGRIA, M.; VARGAS, M.A.T. Establishment of Bradyrhizobium japonicum and B. elkanii in a Brazilian Cerrados oxisol. Biology and Fertility of Soils, v.40, p.28-35, 2004.

NATIONAL CENTER FOR BIOTECHNOLOGY INFORMATION. National Center for Biotechnology Information [home page]. Disponível em: <http://www.ncbi.nlm.nih.gov/>. Acesso em: 22 dez. 2009.

SAAD, M.M.; KOBAYASHI, H.; MARIE, C.; BROWN, I.R.; MANSFIELD, J.W.; BROUGHTON, W.J.; DEAKIN, W.J. NopB, a type III secreted protein of Rhizobium sp. strain NGR234, is associated with pilus-like surface appendages. Journal of Bacteriology, v.187, p.1173-1181, 2005.

SPAINK, H.P.; WIJFJES, A.H.M.; DRIFT, K.M. van der; HAVERKAMP, J.; THOMAS-OATES, J.E.; LUGTENBERG, B.J. Structural identification of metabolites produced by the NodB and NodC proteins of Rhizobium leguminosarum. Molecular Microbiology, v.13, p.821-831, 1994.

SÜSS, C.; HEMPEL, J.; ZEHNER, S.; KRAUSE, A.; PATSCHKOWSKI, T.; GÖTTFERT, M. Identification of genisteininducible and type III-secreted proteins of Bradyrhizobium japonicum. Journal of Biotechnology, v.126, p.69-77, 2006.

VIPREY, V.; GRECO, D.A.; GOLINOWSKI, W.; BROUGHTON, W.J.; PERRET, X. Symbiotic implications of type III protein secretion machinery in Rhizobium. Molecular Microbiology, v.28, p.1381-1389, 1998.

WEI, M.; YOKOYAMA, T.; MINAMISAVA, K.; MITSUI, H.; ITAKURA, M.; KANEKO, T.; TABATA, S.; SAEKI, K.; OMORI, H.; TAJIMA, S.; UCHIUMI, T.; ABE, M.; OHWADA, T. Soybean seed extracts preferentially express genomic loci of Bradyrhizobium japonicum in the initial interaction with soybean, Glycine max (L.) Merr. DNA Research, v.15, p.201-214, 2008.

Recebido em 26 de agosto de 2009 e aprovado em 29 de outubro de 2009 